\title{
Maskuliininen \\ ammatti-identiteetti on huomioitava koulutuksessa ja ohjauksessa
}

\author{
एैy \\ Luopuminen terveydelle haitallisista tavoista saattaa olla \\ vaikeaa, jos tarjolla ei ole riittävän houkuttelevia vaihtoehtoja. \\ Mitä maskuliininen elämäntyyli tarkoittaa työhyvinvointiin \\ liittyvän ohjauksen ja koulutuksen näkökulmasta?
}

TYÖTERVEYSLAITOKSELLA vuosina 2008-2013 toteutetut ammattikuljettajien työhyvinvointiin ja työterveyteen liittyneet kehittämisprojektit tuottivat uutta tietoa ja pohdittavaa kouluttajille ja ohjaajille. Kulttuurisidonnainen maskuliinisuus on kuljetusalalla osa ammatti-identiteettiä. Ammattikuljettajan elämismaailmassa epäterveelliset elintavat vievät usein voiton, koska ne ovat sosiaalisesti hyväksyttyjä ja luovat yhteenkuuluvuuden tunnetta. Tästä syystä työhyvinvointiin ja sairauksien ehkäisyyn tähtäävä, tiedonjakamiseen perustuva opetus ja ohjaus eivät hevin tavoita ammattikuljettajia. Ammattikuljettajien elämänkokemuksen hyödyntäminen sekä tietojen liittäminen ammattiin ja sen erityispiirteisiin helpottavat tiedon omaksumista ja saavat ohjeet tuntumaan merkityksellisiltä. Koska ammattikuljettajien identiteetille on ominaista vapauden kaipuu ja riippumattomuuden tunne, itsemääräämisoikeuden kunnioittaminen on tärkeää ohjauksessa ja koulutuksessa. Kuljettajien omien kokemusten tarkastelun kautta on mahdollista ylittää ammattikulttuurinen raja-aita ja jalkauttaa käytäntöön tietoja ja taitoja, joiden avulla voidaan vaikuttaa kuljettajan ajovireyteen, työhyvinvointiin ja terveyteen.

Kuljetusalalla on ollut vuodesta 2013 lähtien EUdirektiiviin pohjautuen pakollista täydennyskouluttautua " 5 päivää 5 vuodessa" -mallin mukaan (TraFi 2013, EUR-Lex 2003). Ammattikuljettajat istuvat 
usein koulun penkillä opettajien ja kouluttajien ohjattavina. Myös työhyvinvointiin ja työkykyyn liittyvät koulutuspäivät ovat lisääntyneet. Elintavoilla on suuri merkitys hyvää terveyttä vaativassa kuljetusammatissa, koska ammattikuljettajilla epäterveelliset elintavat ja niihin liittyvät sairaudet ovat yleisiä. Sydän- ja verisuonitaudit ja tyypin 2 diabetes lyhentävät työuria ja lisäävät sairaspoissaoloja (Hannerz \& Tüchsen 2001; Tervo \& Neira 2008; Kärmeniemi 2009).

\section{TIEDON SOVELTAMINEN KÄYTÄNTÖÖN TYÖLÄSTÄ}

Vuosien 2008-2013 aikana Työterveyslaitoksella toteutettiin kaksi laajaa ammattikuljettajien terveyden edistämiseen tähtäävää ESR-rahoitteista projektia: Virkeänä ratissa - ruoasta terveyttä tien päälle -hanke ja Nuori kuski osaa! Nuoret ammattikuljettajat työkykyisinä ja työelämätaitoisina ratissa. Tässä artikkelissa näihin kumpaankin hankkeeseen viitataan jatkossa projekteina. Projektien tulosten sekä projekteissa toteutettujen opinnäytetöiden perusteella ammattikuljettajilla on vain keskinkertainen kiinnostus huolehtia omasta terveydestään ja vaalia terveellisiä elintapoja. Kuljettajille oma terveys ja sen hoitaminen näyttäytyivät pääsääntöisesti melko etäisinä asioina.

Virkeänä ratissa -projektin tarkoituksena oli edistää yrittäjä- ja ammattikuljettajien työkykyä ja työvireyttä terveellisen työaikaisen ruokailun keinoin. Vaikka kuljettajat pitivät terveyttä tärkeänä asiana, terveydestä puhuminen ja terveysneuvonta aiheuttivat ahdistusta sekä oman toiminnan ja riippumattomuuden rajoittamisen kokemuksia. Luopuminen vanhoista terveydelle haitallisista tavoista, kuten tupakoinnista, alkoholinkäytöstä ja raskaasta ruoasta, saattaa muodostua vaikeaksi, jos tarjolla ei ole riittävän houkuttelevia vaihtoehtoja. Erään kuljettajan sanoin: "Kaikki kevyt ei oo heleppoo laittaa ja ottaa mukkaan...semmonen pikaruoka on paljo helepompaa”. Toiset kuljettajat ilmaisevat saman vielä ronskimmin: "Seisova pöytä ja siellä mätetää kupu täytee että rutisee, ja yöaikaan kerroshampurilaisateria eikä millään light colalla....."Grillikioski, huoltoasemien baarit, omat matkaeväät, huoltoaseman kahvikupponen”. Laaksosen ja Väinämön (2009) opinnäytetyön tulokset osoittivat, että kuljettajilla oli terveelliseen työaikaiseen ruokailuun liittyvää tietoa, mutta tämän tiedon soveltaminen käytäntöön oli työajan epäsäännöllisyyden vuoksi kovin työlästä.

Pekonen (2001) tutki kulttuuriantropologian pro gradu -tutkielmassa miespuolisten yrittäjä- ja ammattikuljettajien terveyskäyttäytymistä ja elintapoja. Haastatelluista ammattikuljettajista osa oli osallistunut projektin organisoimaan elintapamuutosryhmään. Tulosten perusteella ammattikuljettajien suhde omaan kehoon voi olla melko välineellinen, ja tämä näyttää koskevan kaikkia elintapavalintoja, kuten ruokaa, liikuntaa, terveyttä ja harrastuksia. Liikkumisen ja urheilun sosiaalinen maailma liittyy kuljettajilla usein moottoriajoneuvoihin. Sen lisäksi, että moottoriajoneuvoilla on mahdollista siirtyä nopeammin paikasta toiseen kuin esimerkiksi kävellen, kuljettajat panostivat ajoneuvojen kunnostukseen ja viettivät aikaa niiden parissa samalla intohimolla kuin työautonsa kanssa. "Se ajamisen ilo ja nautinto", totesi eräs kuljettaja haastattelussa. Vaikka kuljettajat ajavat autoa työkseen, he ajavat paljon myös vapaa-ajallaan. Ajaminen luo vapauden tunnetta: "Ei tuu mitkää asiat, työasiatkaa, mielee ku hyppää prätkän selkää. Voi ajaa minne vaa.” Kuljettajien kiinnostuksen kohteet - vapaus, liike ja ajoneuvot - ovat näin laajentuneet harrastuksiksi ja ammatiksi asti. (Pekonen 2011.) Mitä tämä maskuliininen ja motorisoitunut elämäntyyli tarkoittaa työhyvinvointiin liittyvän ohjauksen ja koulutuksen näkökulmasta?

\section{KULTTUURISIDONNAINEN MASKULIINISUUS OSANA AMMATTI-IDENTITEETTIÄ KULJETUSALALLA}

Eteläpellon ja Vähäsantasen (2006) mukaan ammatillinen identiteetti tarkoittaa käsitystä itsestä sosiaa- 
lisena ja ammatillisena, mutta myös persoonallisena ja yksilöllisenä toimijana. Heikkinen tutkijaryhmineen korostaa identiteetin historiallista ja kulttuurista dynaamisuutta. Ammatti-identiteetti kiinnittää ihmisen yhteiskuntaan, mutta se on myös yhteisyyden tuntemista, yhteisiä arvoja, ammattietiikkaa ja osallisuutta ryhmänä sekä itsekunnioitusta ja jonain erityisenä olemista. (Heikkinen ym. 2001, 10-13; Parviainen 2006, 176.)

Identiteetti rakentuu yksilön, ammattiryhmän ja työelämän sekä yhteiskunnan välisissä muuttuvissa suhteissa. Asioiden tärkeysjärjestys ja asiat, joihin työssä sitoudutaan ja kiinnitytään, ovat osa ammatti-identiteettiä. Vahvimpia ammatti-identiteetin rakennusosia ovat ammatillinen koulutus, työtehtävä, työn sisältö, työympäristö ja ammattikunta sekä omat persoonalliset ominaisuudet, tarinat ja työtä tekevä ruumis. Koneiden ja laitteiden hallinta ja taitavuus niiden käytössä ovat osa ammatti-identiteettiä. (Parviainen 2006, 176.) Näiden rakennusosien kautta ammatti-identiteetti ikään kuin puetaan työruumiin eli työtä tekevän ihmisen fyysisen ruumiin (kehon) ylle. Tässä prosessissa työtovereiden ja muiden ihmisten odotuksilla on merkittävä rooli (Pekonen 2011). Antropologinen näkökulma korostaa sitä, miten kulttuuri muovaa ihmisen ruumista sekä ruumiillisuutta koskevia käsityksiä, normeja ja tekniikoita (Kinnunen 2001, 16).

Suomessa kuljetusalan noin 100000 ammattikuljettajasta lähes $90 \%$ on miehiä. Ammatti-identiteettiin sisältyy kulttuurisidonnaisen maskuliinisuuden piirteitä, jotka viittaavat suomalaisessa kulttuurissa hyväksyttyihin tapoihin osoittaa olevansa mies. Kulttuurinen maskuliinisuus määrittää esimerkiksi sitä, miten mies liikkuu, puhuu, ruokailee, pukeutuu, ajattelee, tuntee ja jopa rakastaa. Kulttuurisesti hyväksytyistä tavoista olla mies esiintyy samanaikaisesti useita variaatioita, eli ei ole vain yhtä oikeaa tapaa olla mies tai osoittaa maskuliinisuutta. (Jokinen 2000, 213.) Projekteissamme tuli esiin, että ammattikuljettajan ammatti-identiteetin kulttuuri- sidonnainen maskuliinisuus ulottuu myös terveyskäyttäytymiseen, elintapoihin ja työkyvyn ymmärtämiseen. Haastateltu ammattikuljettaja totesi: "Jos pitäs aatella, että mikä ois enemmän sitä tyyliä niin kai se ois sitte se rasvasempi ruoka"... "Katotaan nyt mikä lopputulos on tällä elämäntyylillä", totesi puolestaan toinen nuori mieskuljettaja uhmakkaasti pohdittuaan omia elintapavalintojaan. (Kemppainen 2011, 44, 50.) Monissa ammateissa, kuten esimerkiksi metalli- ja kuljetusalalla, ammatillista identiteettiä rakennetaan myös sukupolvittain samaistumalla ammattiin "isältä pojalle" -periaatteella. Näin ammatti-identiteetti periytyy myös historiallisesti ja sosiaalisesti (esim. Pettersson 2009).

Heinonen (2006) on tutkinut suomalaisten työväenluokkaisten miesten kulttuuria. Hänen mukaansa työläismiesten asenteet antavat suojaa, kun yhteiskunnallinen ja sosiaalinen asema eivät tarjoa riittävästi mahdollisuuksia puolustaa omia etuja ja itselle merkityksellisiä asioita. Asenteet voivat siis tukea itsetuntoa. Petterssonin (2009) tutkimus ammattikuljettajien suhteesta kontrolliin ja valvontaan tukee Heinosen (2006) havaintoja siitä, että työläistaustaiset miehet voivat hakea asenteistaan suojaa, kun puolustautumisen mahdollisuuksia on muuten heikosti tarjolla.

Petterssonin mukaan kuljetusalan työntekijät eivät hyväksy virallista kontrollia tai sillä on niin sanotusti alhainen legitimiteetti heidän keskuudessaan. Kuljetusalalla on tiukat säännöt ja paljon valvontaa, esimerkiksi ajomatkamittareita ("ajopiirturit") käytetään työaikalainsäädännön noudattamisen seurannassa. Lisäksi on autoiluun liittyviä muita säädöksiä, jotka koskevat kuorman painoa ja ajokalustoa. Petterssonin tutkimuksessa selvisi, että osa ammattikuljettajamiehistä kokee virallisen kontrollin hyvin hallitsevaksi ja pitää sitä merkittävänä osana työnkuvaansa. Tämä koskee ennen kaikkea ajoaikasäädöksiä. Kuljettajien enemmistö piti virallista kontrollia kielteisenä asiana eikä antanut sille korkeaa hyväksyntää. (Pettersson 2009.) 
Heinosen (2006) ja Petterssonin (2009) tulosten kanssa yhdenmukaisesti projektiemme opinnäytetöissä haastatellut kuljettajat etäännyttivät itsensä kontrollia pitävistä tahoista (valtiovalta, poliisi, tulli) ja rakensivat tietoisesti itsetuntoa vahvistavaa asennesuojaa. Vaikka kuljettajien työ on yksinajamista, he pitivät paljon yhteyttä toisiinsa ja pyrkivät rakentamaan yhteistä näkökulmaa asioihin. Tämä toiminta vahvistaa riippumattomuuden tunnetta ja korostaa itsemääräämisvaltaa. Myös nuoret vielä ammattiin opiskelevat ilmaisivat kuljettajakaverin auttamisen ja yhteisöllisyyden olevan heidän suurimpia toiveitaan tulevaa työpaikkaa ajatellessa (Hukkanen \& Salmi 2013). Voimakkaalla yhteenkuulumisen tunteella on myös omat konkreettiset muotonsa, jossa kuljettajat auttavat toisiaan esimerkiksi erilaisten asiakirjojen täyttämisessä tai antavat autoon ja reitteihin liittyviä vinkkejä toisilleen. Pettersson (2009) kutsuu tätä ammattikulttuuriseksi oppimiseksi, jossa rakennetaan tietynlaista arjen käytännöllistä ja normatiivista maskuliinisuutta. Näyttäisikin siltä, että maskuliinisuus on kuljetusalalla merkittävä osa ammatti-identiteettiä, joka näkyy niin yhteiskunnallisella tasolla kuin ryhmä- ja yksilökohtaisestikin. Nämä erityisyydet tulee ottaa huomioon alalle suunnatussa koulutuksessa ja ohjaustyössä.

Osa projekteihin osallistuneista kuljettajista toimi kuljetusliikkeiden palveluksessa, mutta osalla heistä oli oma yritys. Kuljetusalan yrittäjyyteen liittyy omia ammattikulttuurisia tunnusmerkkejä. Yrittäjäkuljettajilta vaaditaan alan yleisten tietojen ja taitojen hallinnan lisäksi myös oman osaamisensa tunnistamista, sen esittämistä ja näkyväksi tekemistä, mikä puolestaan on tärkeä osa markkinointia. Markkinointi ja hyvien työntekijöiden rekrytointi edellyttävät erityistä tietoisuutta omasta ammatillisesta identiteetistä, osaamisesta ja siitä, miten haluaa näkyä ja olla tunnettu alalla. Pien- ja mikroyrittäjävaltaisessa työssä tietoinen identiteetin rakentaminen näyttäytyy vahvana me-henkenä ja jaettuna tietoisuutena omasta ammattikuljettajuudesta.
Habermasille (1981) elämismaailma tarkoittaa ihmisen yksityistä elämänpiiriä, joka on epämuodollisen, kulttuuriin ja kieleen pohjautuvan ymmärtämisen ja mukautumisen arkipäivässä eletty todellisuus. Ammattikuljettajien elämismaailmasta on tunnistettavissa omia, ammattikunnalle erityisiä piirteitään. Ammattikuljettajan elämismaailmassa esimerkiksi epäterveellinen käyttäytyminen vie voiton, koska se tuo mukanaan sosiaalista hyväksyntää ja lisää yhteenkuuluvuuden tunnetta. Ryhmään kuuluminen ja yhteisön tuen saaminen voi siten olla merkityksellisempää kuin terveysneuvojen noudattaminen. (ks. Aukee 2003, 207-208.) Näin ollen kulttuurisesti vieraalta tuntuvan faktatiedon lisääntyminen työhyvinvointia ja terveyttä koskevissa asioissa ammattikuljettajien kohdalla ei välttämättä tuota toivottuja tuloksia.

Vastarinta on muutenkin tyypillistä ammattikuljettajille, mikä ilmenee esimerkiksi vastahankaisena suhteena työaikalakeihin (Pettersson 2009). Kinnarinen (2005) on todennut Mies, talli ja moottoripyörä -pro gradu-tutkielmassaan, että miehet, jotka eivät "kestä arkipäivän rutiineja, etsivät pakotietä arjesta irtaantumiseksi hauskanpidosta ja jännityksestä”. Moottoripyörä tarjoaa tähän oivan välineen. Se antaa lupauksen vapaudesta ja riippumattomuudesta sekä vauhdin tuomasta jännityksestä (vrt. Pettersson 2009). Tutkimuksen miehiä yhdisti myös haluttomuus asettua paikalleen ja rytmittää elämäänsä tasaisemmaksi. Kinnarinen (2005) toteaakin, että vaikka vauhdista pitävät miehet ovat päivätöissä, he ovat usein alalla, joka mahdollistaa paikasta toiseen siirtymisen, tai sitten he ovat tien päällä paljon vapaa-aikanaan.

Kuljetusalaan liittyvien projektiemme haastatteluaineistoista on löydettävissä hyvin samantapaista asennoitumista työhön ja liikkuvuuteen, vaikka aihe kaipaakin lisätutkimusta näiltä osin. Voidaan kuitenkin todeta, että kuljettajat suhtautuivat ajamiseen hyvin intohimoisesti. Vaikka he ajavat työkseen autoa, he ajavat paljon myös vapaa-aikanaan. ”Voi vaan 
painaa kaasua. Antaa mennä," toteaa eräs kuljettaja. "Just se et saa liikkua paikasta toiseen" ja "miksi kävellä, kun voi mennä autolla?" summaavat ajamisen ihanuuden kaksi eri kuljettajaa. Työaikainen ajaminen on monilla kuljettajilla lähes automatisoitunutta toimintaa, mutta vapaa-ajan moottoriurheiluharrastus saa heidänkin silmänsä loistamaan. "Moottoriurheilua harrastan, rallia ajan.” ... ”Prätkä ollut, ehkä uus. Eli kyllä ajaminen itsessään on ehkä se (mun) juttu.” (Laaksonen \& Väinämö 2009; Pekonen 2011; Kemppainen 2011.)

Opinnäytetöiden, tutkimuskirjallisuuden ja kokemusasiantuntijuuden kautta ammattikuljettajan identiteetti näyttää muodostuvan perinteisten sukupuolittuneiden identiteetin rakennusosien lisäksi myös vapauden ja liikkeellä olon arvoista sekä kuljetusalan sukupolvelta toiselle siirtyvästä kulttuurisidonnaisesta maskuliinisuudesta.

\section{AMMATTIKULJETTAJAN MOTORISOITU JA VAPAA ELÄMÄNTYYLI}

Ammattikuljettajilla työhön sitoutuminen on ollut perinteisesti erittäin vahvaa (Salmi, Sallinen \& Laitinen 2010; Pettersson 2009). Mitä kuljettajat tarkoittavat puhuessaan vapaudesta? Vapaus on heille ennen kaikkea valinnanvapautta, vapautta sitoutua työhön omien ehtojensa kautta sekä vapautta sitoutua itseen, omiin mielihaluihin ja toiveisiin.

Vapauden symboliseksi merkitsijäksi nousee ammattikuljettajien haastatteluissa aika, ja nimenomaan oma aika. "Tää työ, on se vapaus joo et kuhan ne hommat hoijan ni kukaa ei oo kattomassa ni onhan se vapaa", toteaa eräs kuljettaja. Vapaiksi itsensä tuntevat kuljettajat kokevat tekevänsä työtä, jossa ei eletä kellokortin tahdissa eikä toisten määräysvallan alla. Vaikka tämä vapaus ei vapauta työnteosta, tärkeää ei niinkään ole se, mitä vapaaksi itsensä kokeva tekee, vaan se, että voi tehdä työnsä niin kuin itseä huvittaa. (esim. Jallinoja 1997, 156.) Todellisuudessa vapaus näyttää olevan kuljetusalalla enemmänkin eräänlainen sukupolvelta toiselle välittynyt ammatillinen ihanne, "king of the road" -haave.
Käytännössä kuljetusala on erittäin säädeltyä, esimerkiksi työlainsäädännön, liikennesääntöjen, toimitusaikataulujen ja äkillisten reittiaikataulumuutosten johdosta (esim. Pettersson 2009). Tästä huolimatta haastateltu nuori kuljettaja toteaa ammattinsa parhaaksi puoleksi: "Vapaus. Saa iha ommaa tahtii touhuta. Ei oo kukkaa selän takana."

Työ on edelleen myös nuoremman sukupolven kuljettajille kunnia-asia, mutta pitkät työpäivät, alhaiset palkkatulot, lisääntyvä kontrolli ja vaikeat työolosuhteet turhauttavat. Ammattikuljettajan sosiaalisesti ja historiallisesti periytyvä identiteetti näkyy kuitenkin myös alalle opiskelevien toiveissa. Ammattiin opiskelevilla nuorillakin on korostunut vapauden kaipuu ja myös tarve sen ilmaisemiseen. (Martikainen 2013; Hukkanen \& Salmi 2013; Pettersson 2009.) Eräs nuori ammattiin opiskeleva kuljettaja totesi: "Se on se veri joka vetää tielle. Mahtaa olla sukuvika." Toisen ammattiin opiskelevan näkemys asiaan on myös vapauden näkökulmasta kiinnostava: "Parasta on, ku joka päivä on erilainen. Siinä on.. se on niinkö aina..ei tiiä aamulla välttämättä, että no mitä nyt tännään tehhään ja missä käyvvään ja..se on ihan erilaista niinkö joka päivä." "Ettei oo semmosta rutiininomaista tuo työ," kuittaa toiveensa kolmas nuori.

\section{TILAA KULJETTAJILLE \\ TARKASTELLA KOKEMUKSIAAN TYÖHYVINVOINTIKOULUTUKSESSA}

Antropologista tutkimusta on tehty erityisesti naisten suhtautumisesta ruokaan, ulkonäköön ja terveellisyyteen. Kulttuurisena ilmiönä ruoka- ja terveyskäyttäytymistä on tutkittu hyödyntäen sosiaalisten suhteiden ja sosiaaliluokkien, hierarkioiden, kontrollin, sukupuolten ja rodun näkökulmia. (Mäkelä 2002, 9-10.) Terveyskäyttäytymistä ei sen sijaan juurikaan ole tutkittu ammatti-identiteetin näkökulmasta. Vaikka terveyteen liittyvää tietoa on paljon, sitä ei osata hyödyntää eri kulttuurisissa konteksteissa, eikä se siten tavoita kaikkia yhteiskuntaluokkia tai ammattikuntia. (Puuronen 2006, 7-9.) 
Vaikka Työterveyslaitoksella toteutetut ammattikuljettajiin kohdentuneet projektimme ovat olleet rahoitukseltaan kehittämisprojekteja, niissä on tehty myös useita opinnäytetöitä ja tutustuttu aitiopaikalta niihin yhteiskunnallisiin, yhteisöllisiin ja yksilöllisiin haasteisiin ja mahdollisuuksiin, joita kuljetusala asettaa ohjaukselle ja neuvonnalle. Havaintojemme perusteella ammattikuljettajat ovat yksi Puurosen (2006) mainitsema ryhmä, jota sairauslähtöinen terveysneuvonta ja hyvinvoinnin edistämiseen tähtäävä ohjaus eivät tavoita. Kulttuurisesti etäiset terveyden uhkatekijöihin ja riskeihin sekä kontrolliin perustuvat terveys- ja hyvinvointiviestit nostattavat ammattikuljettajissa pikemminkin kiukkuista vastarintaa ja saavat aikaan terveyteen liittyvien ilmiöiden kieltämistä.

Kuljettajien ammatti-identiteetille ominainen vapauden kaipuu ja itsemääräämisoikeuden korostuminen on siten hyvä tunnistaa ja ottaa huomioon ohjauksessa ja koulutuksessa. Tietojen ja taitojen siirtämiseksi käytäntöön on tärkeä tarkastella ammattikuljettajien omia kokemuksia siitä, miten epäterveelliset tai terveelliset valinnat vaikuttavat ajovireyteen, työhyvinvointiin ja terveyteen (Kemppainen 2011). Osallistavat ohjausmenetelmät kunnioittavat kuljettajien itsemääräämisoikeutta ja haastavat heidät toimimaan aktiivisesti ja itseohjautuvasti (Laitinen ym. 2014). Koulutuksen ja ohjauksen ammattilaisten ja asiantuntijoiden rooli on siten toimia ennen kaikkea kumppaneina, oppimistilanteiden järjestäjinä, tukijoina sekä vinkkien jakajina (Kemppainen \& Laitinen 2014).

Ammattikulttuurin ja -identiteetin tuntemusta voidaan hyödyntää myös ohjausmenetelmien valinnassa. Ammattikuljettajat muistavat hyvin näkemänsä, joten visuaaliset koulutusmateriaalit on todettu projekteissamme hyödyllisiksi ja toimiviksi. Ohjausmateriaalin ja menetelmien suhteen on tärkeää huomioida monipuolisuus, jotta mahdollisimman moni kiinnostuu ja hyötyy ohjauksesta. Terveyteen liittyvää ohjausta on perinteisesti toteutettu paternalistiseen tyyliin. Tämä tarkoittaa sitä, että tietoa jae-

\section{TERVEYS-

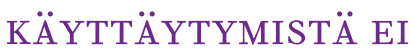 \\ JUURIKAAN OLE TUTKITTU}

AMMATTI-IDENTITEETIN

N ̈̈KÖKULMASTA.

taan, jaettua tietoa pidetään ainoana oikeana vaihtoehtona ja tavoitteena on toiminnan suoraviivainen muuttaminen (Leino-Kilpi 2004, 160-171). Tämä ei todennäköisesti tuota toivottuja tuloksia ammattikuljettajien käyttäytymisessä vaan pikemminkin nostattaa muutosvastarintaa, jolloin käyttäytymismuutoksia ei tapahdu (Mustajoki 2003, 4235-4237). Sen sijaan ohjaaminen siihen, miten toimimalla onnistuu muutoksessa, on tärkeää (Laitinen ym. 2014; Alahuhta ym. 2010).

Tiedon liittäminen ammattikuljettajien työn erityispiirteisiin, ajovireyteen ja ammattikulttuuriin, omien kokemusten tarkasteluun ohjaaminen sekä vertaisten kanssa kokemusten jakaminen saa todennäköisesti koulutuksen ja ohjauksen kiinnostavaksi, ja oppimisen tuntumaan merkitykselliseltä ja mielekkäältä. Oppiminen on kontekstisidonnaista (Tynjälä 2002). Huomion kiinnittäminen onnistumiseen ja siihen, mitä hyvää siitä itselle seuraa, vahvistaa motivaatiota ja tiedon siirtämistä toiminnaksi (Laitinen ym. 2014). On myös taloudellisesti kestävää oppimista hyödyntää oppimis- ja koulutusympäristöinä sitä elämismaailmaa ja kulttuurista yhteisöä, jonka osallisia ammattikuljettajat ovat. (Tjärnstig 2014.)

On yleisesti todettu, että aktiivinen osallistuminen lisää ohjauksen aikaan saamia vaikutuksia käyttäytymisessä (Pignone ym. 2003, 75-92). Myös huumori ja ammatti-identiteettiä vahvistavat myönteiset tun- 
nusmerkit ja voimavarat, kuten esimerkiksi ammattikunnan yhteenkuuluvuus ja vertaistuki, kannattaa ottaa monipuolisesti käyttöön (ks. koulutusmateriaalit www.ttl.fi/virkeanaratissa -> Materiaalit). Riski-, kielto- ja kontrollilähtöistä viestintää on suositeltavaa välttää, jotta koulutettavien ja kouluttajan välille ei synnytetä etäisyyttä ja vahvisteta kulttuurisia suojamuureja.

Työpaikkatason toiminnassa sekä ryhmä- ja yksilöohjauksessa voi käyttää tuottamiamme maksuttomia koulutus- ja ohjausmateriaaleja (www.ttl.fi) virkeanaratissa), jotka on suunnattu erityisesti ammattikuljettajille kuljetusalan työkulttuuri ja ammatti-identiteetti huomioiden. Materiaalit on luotu ja työstetty yhdessä ammattikuljettajien kanssa ja heidän käyttöönsä.

\section{OHJAUKSEN KULTTUURISENSITIIVISYYTEEN KANNATTAA PANOSTAA}

Kuljetusalan kehittämistyö on oiva toimintakenttä, jolla Maailman terveysjärjestön (WHO) terveyden edistämisen viitekehyksen mukaisesti on hyvä suosia ratkaisukeskeisyyttä ja myönteisten, voimavaroja lisäävien tekijöiden esiin nostamista ja korostamista (The Ottawa Charter 1986). Terveyden edistämisen tavoitteena on vaikuttaa yksilöihin, yhteisöihin ja ympäristöön, jotta se tukee terveyttä. Kokemuksemme kuljetusalan kehittämistyöstä korostavat sellaisen koulutuksen ja neuvonnan merkitystä, joka rakentuu ryhmien kulttuuritaustan tuntemiseen ja sen kunnioittamiseen.

Kulttuurisidonnaista terveyskäyttäytymistä on viime vuosina tarkasteltu bourdieulaisittain myös terveyden pääoman näkökulmasta. Tutkimuksen mukaan terveyteen vaikuttavat valinnat ovat yhdistelmä taloudellista, sosiaalista ja kulttuurista pääomaa (Bourdieu 1984, 1986; Singh-Manoux ym. 2005). Kulttuurisidonnainen toiminta, tietämys ja asenteet vaikuttavat siten omalla ainutlaatuisella tavallaan terveyden pääomaan (Abel 2008, 1.) Keskustelu terveyspääomasta ja sen kulttuurisista määreistä on täten kiinnostavaa myös ammatti- ja väestöryhmien välisten terveyserojen kaventamisen näkökulmasta (Rotko ym. 2012). Ammattikuljettajien kulttuurisidonnainen ammattikäyttäytyminen on yksi mahdollinen kulttuurisen pääoman ilmenemistapa, joka voi edesauttaa yksilöitä tekemään sellaisia elintapavalintoja, jotka pitkällä tähtäimellä kasvattavat tai kaventavat terveyseroja eri ammattiryhmien välillä. Näkökulma korostaa kulttuurisensitiivisen ohjauksen tärkeyttä.

Kulttuurisensitiivisyys tarkoittaa kuljetusalalla ennen kaikkea maskuliinisen ammatti-identiteetin tuntemista ja sen huomioon ottamista. Kuljettajan ammattikulttuuriin sovelletussa koulutuksessa ja ohjauksessa on syytä kunnioittaa itsemääräämisoikeutta ja vahvistaa itsestä ja työtovereista huolehtimisen taitoja osana hyvää ammattiosaamista ja työsuojelua. Työhönsä sitoutuneille ammattikuljettajille elintapoja ja työkykyä koskevien asioiden esille ottaminen työn näkökulmasta toimii paremmin kuin sairauksien ehkäisyn viitekehys. Monipuoliset, käyttäjälähtöiset, osallistavat ja ammattikulttuuriin sovitetut ohjausmenetelmät johtavat todennäköisemmin syvätason oppimiseen, jonka myötä tietoja pystytään soveltamaan omassa ammatissa ja käytännön työssä.

Ammattikuljettajien ja kouluttajien väliseen sosiaaliseen vuorovaikutukseen kannattaa siis panostaa. Kun tieto nivoutuu ohjattavien kulttuuriseen ympäristöön ja kokemusmaailmaan, se kolahtaa!

Anne Salmi

FM, antropologi, erityisasiantuntija

Työterveyslaitos

Lea Henriksson

$F T$, dosentti, vanhempi tutkija

Työterveyslaitos

Jaana Laitinen

$F T$, dosentti, tiimipäällikkö

Työterveyslaitos 


\section{LÄHTEET}

Abel, T. (2008). Cultural capital and social inequality in health. The Journal of Epidemiology and Community Health 62(e13): 1-5.

Alahuhta, M., Ukkola, T., Korkiakangas, E., Jokelainen, T., Keränen, AM., Kyngäs, H. \& Laitinen, J. (2010). Elintapamuutosvaihe sekä painonhallinnan onnistumisen edellytykset ja riskitekijät tyypin 2 diabeteksen riskihenkilöillä. Tutkiva Hoitotyö 2: 4-13.

Aukee, R. (2003). Terveyskäyttäytyminen ja sukupuoli. Teoksessa Luoto, R., Viisainen, K. \& Kulmala, I. (toim.). Sukupuoli ja terveys. Jyväskylä: Gummerus Kirjapaino Oy.

Bourdieu, P. (1984). Distinction: A social critique of the judgement of taste. Cambridge: Harvard University Press.

Bourdieu, P. (1986). The forms of capital. Teoksessa: Richardson, JG. Toim. Handbook of theory and research for the sociology of education. Connecticut: Greenwood Press.

Eteläpelto, A. \& Vähäsantanen, K. (2006). Ammatillinen identiteetti persoonallisena ja sosiaalisena konstruktiona. Teoksessa Eteläpelto, A. \& Onnismaa, J. (toim.) Ammatillisuus ja ammatillinen kasvu. Vantaa: Kansanvalistusseura.

EUR-Lex. (2003). Euroopan parlamentin ja neuvoston direktiivi 2003/59/EY, http:// eur-lex.europa.eu/LexUriServ/LexUriServ. do?uri=CELEX:32003L0059:FI:NOT Luettu 26.3.2014.

Habermas, J. (1981). Theorie des kommunikativen Handelns. Suhrkamp: Neuauflage.

Hannerz, H. \& Tüchsen, F. (2001). Hospital admissions among male drivers in Denmark. Occupational and Environmental Medicine 58: 253-260.

Heikkinen, A., Borgman, M., Henriksson, L., Korkiakangas, M., Kuusisto, L., Nuotio, P. \& Tiilikkala, L. (2001). Niin vähän on aikaa ammatillisen kasvun katoava aika, paikka ja tila? Tampere: Ammattikasvatuksen tutkimus- ja koulutuskeskus, Tampereen yliopisto.

Heinonen, J. (2006). Työläismies ahdingossa? Kolme sukupolvea rakennemuutosten Suomessa. Helsinki: Yliopistopaino.

Hukkanen, L. \& Salmi, A. (2013). Millaisia toiveita ja odotuksia nuorilla on kuljetusalaa kohtaan? Rahtarit 6: 37-38.
Jallinoja, R. (1997). Moderni säädyllisyys - aviosuhteen vapaudet ja sidokset. Tampere: Gaudeamus.

Jokinen, A. (2000). Panssaroitu maskuliinisuus: mies, väkivalta ja kulttuuri. Tampere: Yliopistopaino.

Kemppainen, S. \& Laitinen, J. (2014). Pyöräytä ammattikuljettajan rattia kohti työhyvinvointia. Työterveyshoitaja 1: 26-27.

Kemppainen, S. (2011). Nuorten ammattikuljettajien näkemyksiä ruokatottumuksistaan - onko äijäruokakulttuuria enää olemassa? Kuopio: ItäSuomen yliopisto.

Kinnarinen, K. (2005). Mies, talli ja moottoripyörä. Etnografinen tutkimus Misfit Mc:stä ja bikerkulttuurin eetoksesta. Turku: Turun yliopisto.

Kinnunen, T. (2001). Pyhät bodarit. Helsinki: Gaudeamus.

Kärmeniemi P., Laitinen J., Latvala J., Olkkonen, S., Sainio, M. \& Ylä-Outinen, A. (2009). Maantieliikenteen ammattikuljettajien työterveyshuolto. Helsinki: Työterveyslaitos.

Laaksonen, E. \& Väinämö, M. (2009). Virkeänä ratissa - lin taksinkuljettajien näkemyksiä terveellisen työaikaisen ruokailun merkityksestä työkyvylle. Kemi: Kemi-Tornion ammattikorkeakoulu.

Laitinen, J., Alahuhta, M., Keränen, AM., Korkiakangas, E. \& Jokelainen, T. (2014). Painon hallitsija. Ryhmäohjaajan opas. Helsinki: Työterveyslaitos. Painossa.

Leino-Kilpi, H. (2004). Terveyden edistämisen etiikka. Teoksessa Leino-Kilpi, H. \& Välimäki, M. Etiikka hoitotyössä. Juva: WSOY, 160-171.

Martikainen, M. (2013). Saat mennä ku mielenkipee tuolla noin ja silti oot myöhässä - Linja-autonkuljettajien käsityksiä työhyvinvoinnista. Helsinki: Helsingin yliopisto.

Mustajoki, P. (2003). Miten potilas motivoituu hoitonsa aktiiviseksi osapuoleksi? Suomen Lääkärilehti 42: 4235-7.

Mäkelä, J. (2002). Syömisen rakenne ja kulttuurinen vaihtelu. Helsinki: Kuluttajatutkimuskeskus.

Parviainen, J. (2006). Meduusan liike. Mobiiliajan tiedonmuodostuksen filosofiaa. Helsinki: Gaudeamus.

Pekonen, H. (2011). Miehet ratin takana. Tutkielma ammattikuljettajien terveyskäyttäytymisestä ja elintavoista vuonna 2010. Oulu: Oulun yliopisto. 
Pettersson, L. (2009). Frihet under kontroll - om kontroll i åkerinäringen. Stockholm: Stockholm universitet.

Pignone, MP., Ammerman, A., Fernandez, L., ym. (2003). Counseling to Promote a Healthy Diet in Adults. A Summary of the Evidence for the U.S. Preventive Services Task Force. American Journal of Preventive Medicine 24(1):75-92.

Prochaska, J., DiClemente C. \& Norcross J. (1992). In search of how people change. American Psychologist 47(9): 1102-1114.

Puuronen, A. (2006). Terveystaju: nuoret, politiikka ja käytäntö. Helsinki: Nuorisotutkimusseura.

Richardson, JG. Toim. (1986). Handbook of theory and research for the sociology of education. Connecticut: Greenwood Press.

Rotko, T., Kauppinen, T., Mustonen, N. \& Linnanmäki, E. (2012). Kuilun kaventajat - Kansallinen terveyserojen kaventamisen toimintaohjelma 2008-2011 -loppuraportti. Helsinki: Terveyden ja hyvinvoinnin laitos THL.

Salmi A., Alahuhta M. \& Laitinen, J. (2009). Pysyvä muutos voi vaatia monia yrityksiä. Taksi 4: 34-35.

Salmi, A., Sallinen, J. \& Laitinen, J. (2010). Pidä kohtuus työajassa - kukaan ei jaksa venyä loputtomasti. Taksi 3: 34-35.

Singh-Manoux, A. \& Marmot, M. (2005). Role of socialisation in explaining social inequalities in health. Social Science \& Medicine 60: 2129-33.

Tervo, T. \& Neira, W. (2008). Ajoterveyden valvontaa pitää kehittää. Suomen Lääkärilehti 63(20): 18591863.

The Ottawa Charter. International Conference on Health Promotion. (1986). World Health Organization, www. who.int/healthpromotion/conferences/previous/ ottawa/en/ Luettu 26.3.2014.

Tjärnstig, L. (2014). Tutkimusprojekti.

Tiedonrakentaminen steinerkoulussa.

Steinerkasvatus 1: 30-33.

TraFi. (2013). Kuljettajan ammattipätevyys, www.trafi. fi/tieliikenne/ammattiliikenne/kuorma_ja_linjaautonkuljettajien_ammattipatevyys Luettu 26.3.2014.

Tynjälä, P. (2002). Oppiminen tiedon rakentamisena. Konstruktivistisen oppimiskäsityksen perusteita. Helsinki: Kirjayhtymä. 